\title{
Compreensão da educação escolar a partir do estudo de Martin Buber
}

\section{Understanding school education based on the study by Martin Buber}

\section{Comprensión de la educación escolar a partir del estudio de Martin Buber}

Alinne Monteiro da Cruz Atanasio Instituto Federal de Educação, Ciência e Tecnologia de Goiás (Brasil)

PARREIRA, Gizele Geralda. Martin Buber e o sentido da educação. Goiânia: Editora IFG, 2016.

O livro Martin Buber e o sentido da educação, escrito pela docente e psicóloga Gizele Geralda Parreira, apresenta uma leitura crítica acerca da vida e obra de Martin Buber (1878-1965), filósofo e professor vienense, judeu hassidista, cuja formação compreendeu as áreas de Filosofia, História da Arte, História da Literatura, Sociologia, Psiquiatria e Economia e possibilitou contato com diversos autores, como Kant, Nietzche, Dilthey, Herzl, Kierkegaard, Feverbach, Gustav-Landaver, Franz Rosenzweig. A partir desses autores, Buber construiu suas próprias reflexões, pautando-se na análise do homem da era moderna e da sociedade capitalista e industrial, sujeita à excessiva valorização da técnica e de fatores econômicos como norteadores da vida humana. Nesse contexto, o ser humano torna-se meio para elevar os percentuais lucrativos e alcançar metas ao priorizar a produtividade e a sobrevivência em detrimento do viver genuíno e comunitário.

Com clareza, precisão e didática o livro visa a ressignificar a ação educadora a partir das concepções dialógicas buberianas, sobretudo, por meio do resgate da essência humana e da capacidade de encontrar e dialogar com o outro. Hodiernamente, compromete-se a realização do homem como homem, em decorrência de relações mecânicas, frívolas e superficiais, em que o semelhante é visto somente de forma utilitária, relegando-o a uma vivência solitária, individualista e coisificada.

Em tal contexto, a escola e as relações nela estabelecidas não permanecem alheias e são afetadas nesse processo. Muito tem se perdido acerca do 
cultivo da humanidade neste ambiente, assim como a formação humana, integral, autônoma e emancipada do aluno tem sido relegada a segundo plano, tornando-se uma formação transmissiva, mecanicista, produtivista, clientelista, arbitrária e impositiva.

Desenvolvida em três capítulos, a obra destaca a retomada do diálogo e do encontro como essenciais para o desenvolvimento da humanidade, algo que extrapola o caráter comunicativo e a mera ocupação do mesmo ambiente, pois implica a perspectiva do homem como ser relacional, altruísta, que se coloca face a face em uma atitude recíproca de abertura ao outro e de valorização deste em sua humanidade.

Para tanto, a autora postula a relevância da educação dialógica e comunitária, cuja ruptura com os paradigmas tradicionais de ensino concorram para a construção de um novo caminho de consolidação das relações realmente humanas. Assim, a leitura do livro em resenha torna-se significativa à medida que nos convida a analisar as implicações da sociedade capitalista e industrial na vivência humana e nas práticas pedagógicas, bem como a pensar uma formação efetiva a partir do resgate da essência humana. Adentremos, portanto, pelos capítulos da obra.

No primeiro capítulo, Parreira situa o leitor sobre a biografia de Martin Buber, sob a demonstração de que a trajetória humana, acadêmica e profissional do filósofo fundamentou e ratificou os postulados dialógicos acerca da compreensão humana. A professora destaca a atualidade dos estudos buberianos, ao passo que, inserido em uma sociedade pautada na expansão produtiva e na ampliação dos lucros, o homem experimenta a usurpação da sua humanidade e amarga a objetificação, a escravidão e o abandono do seu ser.

À luz do pensamento buberiano, propõe-se a reflexão de que a plenitude do ser se desenvolve em contexto relacional, portanto, é premente a ruptura das barreiras e das distâncias que impedem a realização do diálogo e fomentam a vida solitária e esvaziada de sentido.

capítulo seguinte apresenta o detalhamento das palavras-princípios Eu-Tu e Eu-lsso, como formas do homem se colocar diante do outro. O Eu-Tu concebido sobre os laços do envolvimento, da tomada de conhecimento íntimo, do diálogo genuíno, da relação inter-humana, possibilita acessar e adentrar o mundo um do outro, reciprocamente, mediante a percepção de que ambos 
são seres singulares que se colocam integralmente na relação com o seu semeIhante, disponíveis para a troca dialógica e para a transformação subjetiva. Enquanto que o Eu-lsso engendra pela rota da experiência, da observação e dos fatores externos ao homem, aspectos relevantes para a formação humana, porquanto possibilita a organização, a objetividade e a estruturação de diversas instâncias sociais, inclusive do saber científico e normativo.

Contudo, o óbice encontra-se na predominância do Eu-lsso sobre o Eu-Tu, principalmente, na coisificação, na instrumentalização e na limitação dos diálogos humanos desvanecidos da alteridade e da essência do ser. Parreira destaca o equilíbrio entre o Eu-Tu e o Eu-Isso para a consolidação de uma vida dialógica, em que as partes estabeleçam alternância e não sobreposição.

A autora pondera ainda a necessidade de se estabelecer relações que demonstrem um olhar e uma atitude diferenciada concernente ao outro, livre de preconceitos, de estereótipos e de estranhamentos. Porém, precipuamente, essas relações são reveladas em verdadeiros encontros, os quais não se limitam a eventos sociais, mas englobam o fator inter-humano que se concretiza de modo autêntico e consciente no ato de voltar-se para o outro.

No último capítulo, considerando o papel da essência humanizadora do homem, Parreira reconhece a relevância da educação dialógica e da ressignificação das práticas de ensino. Isso leva a uma mudança de paradigma, que se alicerça na ruptura com o processo hierarquizado, informativo, acrítico e distante, no qual professor e aluno possuem uma convivência diária, mas que não se traduz numa relação significativa. É o conteudismo que regula as relações e determina os papéis: professor como detentor da verdade e aluno como depósito do saber. Entretanto, a autora defende que o sentido da educação decorre da interação dialógica, em que ensinar e aprender sejam ações concomitantes e mútuas, nas quais haja prioridade para o desenvolvimento relacional humano, com a verdadeira valorização do aluno como pessoa e não como uma versão objetificada.

Assim, com a tomada de conhecimento do aluno e por meio da influência docente, pressupõem-se as práticas de ensino como conciliadoras da construção do conhecimento e da formação do caráter. Estas devem ser desenvolvidas de forma autêntica e consciente pelo educador, cuja postura fundamenta-se não no diálogo técnico ou monológico, mas no modo genuíno de interagir. 
Nesse sentido, na filosofia buberiana, concebe-se a escola como um espaço de comunitariedade, onde se destrona a violência, os extremismos e as imposições, buscando-se a consolidação do ambiente escolar como campo de relações verdadeiras, em que se priorize o olhar e as contribuições dos outros para aperfeiçoar as potencialidades humanas.

Com essa experiência relacional e a transformação individual, vislumbra-se a edificação de uma nova comunidade, além da ordem social vigente, com vivências reais e naturais voltadas à liberdade e à vida com propósito e plena de humanidade.

Com efeito, a obra resenhada tece reflexões sobre a realidade, não como descritora das mazelas, mas sob o incentivo a empreender relações significativas, a retomar valores e a rever a prática pedagógica, colaborando, pois, para uma aprendizagem efetiva e para a transformação do ser humano. Portanto, torna-se oportuna a adoção deste livro nos cursos de formação de professores, inicial e continuada, uma vez que preconiza o resgate da essência humana e o diálogo como diretrizes para as relações, com o reconhecimento da ação educadora como caminho, inclusive, para a construção de uma nova e autêntica comunidade.

Mestranda Alinne Monteiro da Cruz Atanasio Instituto Federal de Educação, Ciência e Tecnologia de Goiás (Brasil) Programa de Pós-Graduação em Educação Profissional e Tecnológica Grupo de Estudos e Pesquisas em Psicologia e Educação - Dynamis Orcid id: 0000-0002-3530-2477 E-mail: alinnemca@yahoo.com.br Recebido 22 ago. 2019 Aceito 13 dez. 2019 